\title{
The aggregation behavior and interactions of yak milk protein under thermal treatment
}

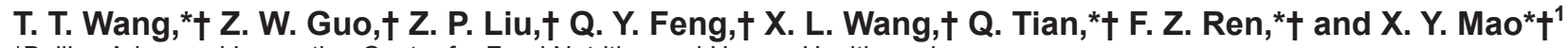 \\ *Beijing Advanced Innovation Center for Food Nutrition and Human Health, and \\ †Key Laboratory of Functional Dairy, Ministry of Education, College of Food Science and Nutritional Engineering, China Agricultural University, \\ Beijing 100083, China
}

\section{ABSTRACT}

The aggregation behavior and interactions of yak milk protein were investigated after heat treatments. Skim yak milk was heated at temperatures in the range of 65 to $95^{\circ} \mathrm{C}$ for $10 \mathrm{~min}$. The results showed that the whey proteins in yak milk were denatured after heat treatment, especially at temperatures higher than $85^{\circ} \mathrm{C}$. Sodium dodecyl sulfate-PAGE analysis indicated that heat treatment induced milk protein denaturation accompanied with aggregation to a certain extent. When the heating temperature was 75 and $85^{\circ} \mathrm{C}$, the aggregation behavior of yak milk proteins was almost completely due to the formation of disulfide bonds, whereas denatured $\alpha$-lactalbumin and $\beta$-lactoglobulin interacted with $\kappa$-casein. When yak milk was heated at 85 and $95^{\circ} \mathrm{C}$, other noncovalent interactions were found between proteins including hydrophobic interactions. The particle size distributions and microstructures demonstrated that the heat stability of yak milk proteins was significantly lowered by heat treatment. When yak milk was heated at 65 and $75^{\circ} \mathrm{C}$, no obvious changes were found in the particle size distribution and microstructures in yak milk. When the temperature was 85 and $95^{\circ} \mathrm{C}$, the particle size distribution shifted to larger size trend and aggregates were visible in the heated yak milk.

Key words: yak milk protein, thermal aggregation, disulfide bonds, hydrophobicity, SDS-PAGE

\section{INTRODUCTION}

The yak, which is distributed on the Qinghai-Tibetan Plateau at altitudes above $3,000 \mathrm{~m}$, is a rare and valuable bovine species. Yak milk products are gaining in

Received February 20, 2016.

Accepted March 28, 2016.

${ }^{1}$ Corresponding author: maoxueying@cau.edu.cn popularity due to their special nutritional value. To promote the industrialization of yak milk products, it is necessary to investigate the physico-chemical properties of yak milk, particularly the heat stability characteristics of yak milk proteins (Li et al., 2014).

Heat treatment is one of the essential steps widely used in industrial dairy processes for either improving the technological-functional properties of dairy products or ensuring their safety and shelf life (Oldfield et al., 2000). It can reduce the number of microorganisms, but may result in a certain degree of protein denaturation. Inappropriate thermal intensity can lead to product browning, protein precipitation, and other quality issues (Taterka and Castillo, 2015). The effect of thermal treatment on the stability of milk proteins mainly concentrate on the denaturation of whey proteins and cross linking between whey proteins and casein micelles. Heat-induced casein/whey protein interactions in cow milk have been reported (Rattray and Jelen, 1997; Boye and Alli, 2000; Oldfield et al., 2000). The $\beta-\mathrm{LG}$ of bovine milk will be denatured and crosslinked with $\kappa$-casein at a certain heating intensity (Anema, 2000; Guyomarc'h et al., 2003). When heating intensity increases further, $\alpha$-LA also begin to denature, form complexes with denatured $\beta-\mathrm{LG}$, and attach to the surface of casein micelles (Corredig and Dalgleish, 1996). It has been shown that the main contributor to thickening of milk after heating at low $\mathrm{pH}$ is the variation in the ratio of casein to whey protein when the serum mineral composition is the same. The higher the proportion of whey proteins in total protein composition, the lower the gelation temperature, and the more susceptible the milk is to thickening (Singh et al., 2015). Casein is capable of controlling the aggregation behavior of heat-induced denatured whey proteins, even at acidic pH values (O'Kennedy and Mounsey, 2006). Besides, the heat stability of low-heat skim milk powder could be improved by reducing free $\mathrm{Ca}^{2+}$ concentration of the original milk, suggesting that free $\mathrm{Ca}^{2+}$ concentration in milk can be used as an indicator of the heat stability of skim milk (Faka et al., 2009). 
The content of TS (16.9-17.9\%), proteins (4.9-5.9\%), and fat $(5.5-7.5 \%)$ of yak milk is higher than that in cow milk (Li et al., 2010). With regard to protein fractions, yak milk contains more protein and caseins than cow milk (Li et al., 2010). Total casein content of yak milk (40.2 g. $\mathrm{L}^{-1}$ on average) is 1.5 times the concentration of cow milk. Compared with cow caseins, yak caseins contain more $\alpha_{\mathrm{S}^{-}}$and $\beta$-casein and less $\alpha_{\mathrm{S}^{-}}$and $\kappa$-casein (Wang et al., 2013). The ratio of whey protein in the total protein of yak milk is higher than that of cow milk as well (Li et al., 2010). Because whey proteins are more heat-sensitive than caseins, the whey protein ratio differences may influence the interactions between whey proteins and caseins in heated yak milk, which leads to aggregation behavior variances. Besides, the major mineral contents of yak milk are much higher than those of cow milk, including calcium ( $\mathrm{Li}$ et al., 2011). The existence of more calcium may reduce the solubility of proteins and induce protein aggregation (Vyas and Tong, 2004). Therefore, due to the differences of protein composition and calcium content between cow milk and yak milk, the heat stability and proteins aggregation of yak milk may also be different. Therefore, it is necessary to investigate the heat stability of yak milk protein and demonstrate the differences from cow milk.

Until now, little research has been conducted on the heat stability of yak milk protein, including the effect of heat treatment temperature and duration on yak micellar casein and the effect of $\mathrm{pH}$ on yak milk proteins (Li et al., 2014; Yang et al., 2014; Xu et al., 2015). But the effect of thermal treatment on yak milk system still need to be explored. Therefore, the objective of this study was to assess the effect of thermal treatment on the stability and interactions of yak milk proteins. Whey protein denaturation degree, surface hydrophobicity, surface sulfhydryl content, and heat-induced denaturation and interactions of yak milk proteins after different heat treatments were investigated. The particle size distribution and protein aggregation microstructures after heat treatment were also evaluated. Our findings may provide a good understanding about thermal stability of yak milk, which could be helpful to the technological design of yak milk processing.

\section{MATERIALS AND METHODS}

\section{Materials and Reagents}

Skim yak milk was provided by Aba Ruoergai county (Sichuan, China). 8-Anilino-1-naphthalenesulfonic acid (ANS) and 5,5'-dithio-bis2-nitrobenzoic acid (DTNB) were obtained from Sigma Chemical Co. (St. Louis, $\mathrm{MO})$. All other chemicals were reagent grade.

\section{Heat Treatment of Skim Yak Milk}

Skim yak milk was heated in 5-mL aliquots at 65,75 , 85 , and $95^{\circ} \mathrm{C}$, respectively, for $10 \mathrm{~min}$ in test tubes in a temperature-controlled water bath. After treatment, the yak milk was immediately cooled to room temperature with ice-water bath.

\section{Determination of Whey Protein Nitrogen Index}

Aliquots of 5-mL heated yak milk were added with 2 $\mathrm{g}$ of $\mathrm{NaCl}$, sealed with stoppers, and stored in a water bath at $37^{\circ} \mathrm{C}$ for $30 \mathrm{~min}$. The tubes were shaken for 15 min and then kept at a standstill. The mixture was filtered through S \& S no. 602, 9-cm-filter paper without cooling. The filtrates were added with saturated $\mathrm{NaCl}$ solution (1.8:4, vol/vol), and the diluted solutions were capped and slowly inverted. Then, $2 \mathrm{~mL}$ of $10 \%$ $\mathrm{HCl}$ (wt/vol) was added, the solutions were kept at a standstill for $10 \mathrm{~min}$, subsequently poured into the cuvette, and the absorbance was measured at $420 \mathrm{~nm}$. The measured values were corrected with the buffer (saturated $\mathrm{NaCl}$ solution with corresponding amount of $10 \% \mathrm{HCl})$.

\section{SDS-PAGE Analysis}

The protein composition of yak milk was determined by SDS-PAGE according to the method of Laemmli (1970). Heated yak milk was diluted 3-fold by deionized water, then prepared under reducing conditions with $\beta$-mercaptoethanol (BME; SDS-R-PAGE) and nonreducing conditions (without $\beta$ ME; SDS-NR-PAGE) to determine the role of disulfide bonds. The dispersions were vortexed, boiled for 5 min, and cooled down. Ten microliters of protein solution containing $30 \mu \mathrm{g}$ of proteins was injected to all wells. The samples were electrophoresed with a 5\% stacking gel and a 12.5\% polyacrylamide resolving gel using a Mini-Protean electrophoresis system (Bio-Rad Laboratories Inc., Hercules, CA). After electrophoresis, the gels were stained with Coomassie Blue R-250 (Bio-Rad Laboratories Inc.) and then destained with a water-methanol-acetic acid mixture $(8: 1: 1, \mathrm{vol} / \mathrm{vol} / \mathrm{vol})$ until the background was clear. PageRuler Unstained Protein Ladder (Thermo Scientific, Waltham, MA) consisting of proteins in the range from 10 to $200 \mathrm{kDa}$ was used as a molecular weight standard.

\section{Determination of Surface Sulfhydryl Content}

Surface sulfhydryl (SH) content in the heated yak milk was determined using Ellman's reagent according to the method described by Beveridge et al. (1974). 
Aliquots of $0.5 \mathrm{~mL}$ of heated yak milk were diluted with $7 \mathrm{~mL}$ of deionized water. One milliliter of diluted yak milk was mixed with $5 \mathrm{~mL}$ of buffer $(0.086 M$ Tris, 0.09 $M$ Gly, $4 \mathrm{~m} M$ EDTA, $8 M$ urea, $\mathrm{pH} 8.0$ ); then, $0.04 \mathrm{~mL}$ of Ellman's reagent (DTNB $4 \mathrm{mg} / \mathrm{mL}$, DTNB dissolved in the same buffer mentioned above but without urea) was added and the mixture was held for $10 \mathrm{~min}$. The absorbance at $412 \mathrm{~nm}$ was measured with a Unico spectrophotometer (Unico Instrument Co. Ltd., Shanghai, China). The surface SH contents were calculated and expressed as micromoles per gram of sample:

$$
\mathrm{SH}(\mu \mathrm{mol} / \mathrm{g})=\left(73.53 \times \mathrm{A}_{412} \times \mathrm{D}\right) / \mathrm{C},
$$

where $\mathrm{A}_{412}$ is the absorbance at $412 \mathrm{~nm}$ of sample; $\mathrm{D}$ is the dilution factor, $\mathrm{D}=6.04 \times 15=90.6$; and $\mathrm{C}$ is the solid content of the sample $(\mathrm{mg} / \mathrm{mL})$.

\section{Determination of Surface Hydrophobicity}

Surface hydrophobicity was determined according to the method described by Alizadeh-Pasdar and Li-Chan (2000). Heated yak milk was diluted by the addition of PBS buffer (0.01 $M, \mathrm{pH} 7.0)$ to make protein concentrations between 0.0025 and $0.0125 \%$ (wt/ vol). Aliquots of $1 \mathrm{~mL}$ above diluted solutions were diluted 5-fold by deionized water, shaken, and mixed well. The surface hydrophobicity was determined using fluorescence probe ANS. Forty microliters of $8 \mathrm{mM}$ ANS buffer was added, and the solutions were kept at a standstill for $10 \mathrm{~min}$. The relative fluorescence intensity of the samples was measured using a fluorescence spectrophotometer (Shimadzu model RF-5301PC, Kyoto, Japan) at room temperature $\left(25^{\circ} \mathrm{C}\right)$, the excitation and emission wavelength were 390 and $470 \mathrm{~nm}$, respectively, with a constant excitation and emission slit of $5 \mathrm{~nm}$. Samples without ANS addition were used as blanks. Protein concentration was determined by BCA assay (Smith et al., 1985).

\section{Particle Size Distribution}

Aliquots of $0.5 \mathrm{~mL}$ of heated yak milk were diluted 10fold by deionized water. The particle size distribution of yak milk was measured by a Delsa Nano C particle size analyzer (Beckman Counter Inc., Fullerton, CA).

\section{Microstructure Observation by Laser Scanning Confocal Microscope}

Heated yak milk were added with Rhodamine B dye at a concentration of $0.1 \mathrm{mg} / \mathrm{mL}$ and mixed well. Aliquots of $100-\mu \mathrm{L}$ solutions were dropped into glass slides with grooves and a coverslip. The microstructure of heated yak milk was observed by laser scanning confocal microscope (LSM710, Zeiss Co., Oberkochen, Germany) with a $100 \times$ oil immersion objective (numerical aperture $=1.4$ ) at the excitation wavelength of $568 \mathrm{~nm}$ and recorded by photographs.

\section{Observation by Optical Microscope}

Aliquots of $20 \mu \mathrm{L}$ of heated yak milk were spread out on the microscope slides and observed by an optical microscope (XSZ-4G, Optical \& Electrical Instrument Co., Chongqing, China) with a magnification of 200 times.

\section{Statistical Analysis}

All data were expressed as means \pm standard deviation from 3 independent trials. Statistical analysis was performed with SPSS software (version 17.0, SPSS Inc., Chicago, IL). The differences between mean values of multiple groups were analyzed by one-way ANOVA and Tukey's multiple-comparison test. Values reported as significantly different were expressed at $P<0.05$.

\section{RESULTS}

\section{Effect of Heat Treatment on Denaturation Degree of Yak Whey Proteins}

Whey protein nitrogen index was expressed as the optical density (OD) value $(420 \mathrm{~nm})$ to demonstrate the denaturation degree of whey proteins. Figure 1 shows that the OD value decreased significantly with the enhancement of temperature. At 65 and $75^{\circ} \mathrm{C}$, the $\mathrm{OD}$ value decreased slowly. When the temperature was higher than $85^{\circ} \mathrm{C}$, the $\mathrm{OD}$ value decreased more significantly and reached the minimum at $95^{\circ} \mathrm{C}$, which was much lower than that of the unheated samples (at $25^{\circ} \mathrm{C}$ ). The lower OD value was, the more denatured whey protein was in the heated yak milk.

\section{Aggregation Characteristics of Yak Milk Proteins Under Heat Treatment}

To further explore the thermal stability and thermal aggregation characteristics of yak milk proteins, SDSR-PAGE and SDS-NR-PAGE analysis were conducted. For SDS-NR-PAGE analysis, as shown in Figure 2 (lanes 1-5), aggregate I began to occur at $75^{\circ} \mathrm{C}$ (lane 3 ) and increased with the enhancement of temperature. At the same time, the content of caseins and whey proteins decreased with the temperature increasing from 75 to $95^{\circ} \mathrm{C}$ and from 85 to $95^{\circ} \mathrm{C}$, respectively. In addition, the 
decrement of whey proteins was more significant than caseins, and the whey proteins almost disappeared at $95^{\circ} \mathrm{C}$. The results demonstrate that yak milk proteins begin to aggregate at $75^{\circ} \mathrm{C}$ and the aggregation mainly happened with $\alpha$-LA and $\beta$-lactoglobulin. For the SDSR-PAGE analysis, as shown in Figure 2 (lanes 6-10), aggregates II were not found below $75^{\circ} \mathrm{C}$ and aggregate I only appeared at $95^{\circ} \mathrm{C}$. Meanwhile, the denaturation level of caseins and whey proteins were lower than that in SDS-NR-PAGE. The SDS-PAGE patterns indicated that the aggregation behaviors of yak milk proteins were almost completely due to the formation of disulfide bonds between proteins when heated at 75 and $85^{\circ} \mathrm{C}$. As the temperature was increased further to $95^{\circ} \mathrm{C}$, other interactions might occur besides thiol/ disulfide exchange interactions.

\section{Changes of Surface Sulfhydryl Content in Yak Milk After Heat Treatment}

To investigate thiol/disulfide exchange interactions in heated yak milk, the content of surface sulfhydryl group was measured. As shown in Figure 3, the content of surface sulfhydryl group increased with the enhancement of temperature. The surface sulfhydryl content increased slowly at 65 and $75^{\circ} \mathrm{C}$, then increased sharply at $85^{\circ} \mathrm{C}$ and reached the maximum at $95^{\circ} \mathrm{C}$.

\section{Effect of Heat Treatment on Surface Hydrophobicity Index}

To determine whether hydrophobic interactions played a role in the formation of protein aggregates, the surface hydrophobicity of heated yak milk was estimated using ANS as fluorescence probe. The higher

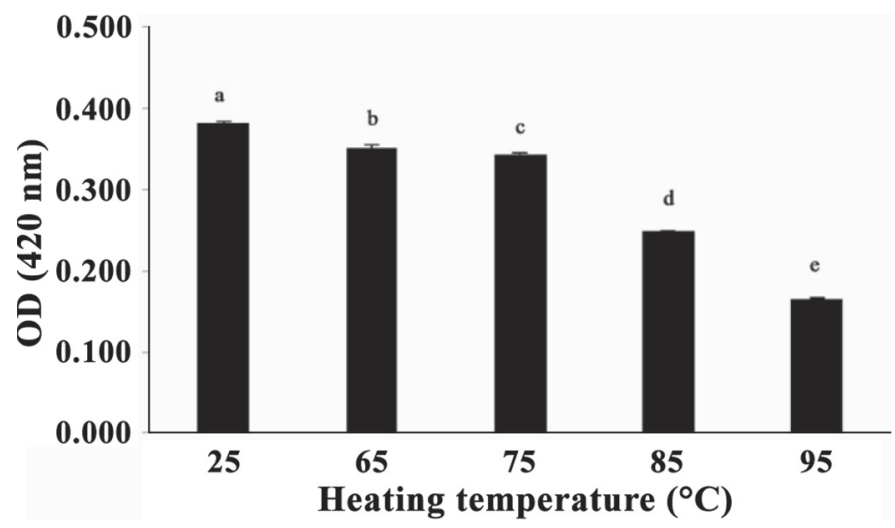

Figure 1. The whey protein nitrogen index, expressed as optical density (OD), of yak milk samples after being heated at 25, 65, 75, 85 , and $95^{\circ} \mathrm{C}$ for $10 \mathrm{~min}$, respectively. Different letters (a-e) indicate significant differences $(P<0.05)$ among samples. Error bars represent $\mathrm{SD}$ of 3 independent experiments.

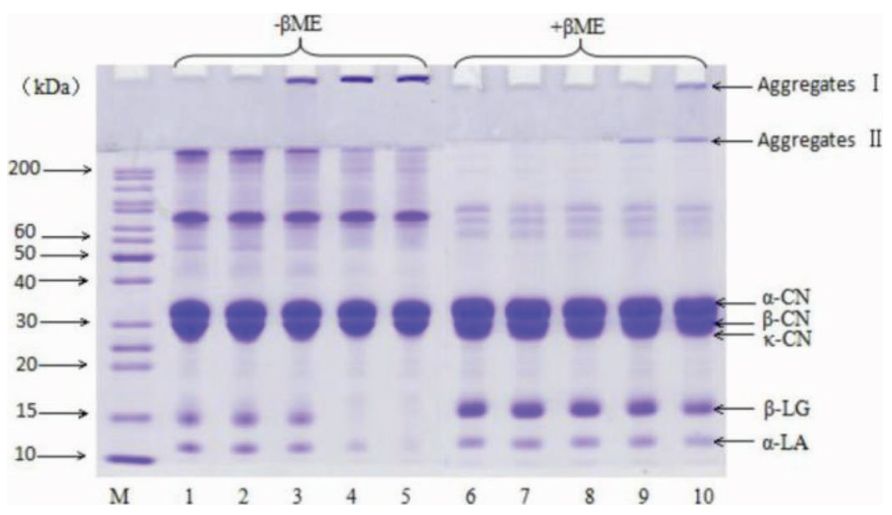

Figure 2. Sodium dodecyl sulfate-PAGE patterns of yak milk samples after being heated at $25^{\circ} \mathrm{C}$ (lanes 1 and 6 ), $65^{\circ} \mathrm{C}$ (lanes 2 and 7), $75^{\circ} \mathrm{C}$ (lanes 3 and 8 ), $85^{\circ} \mathrm{C}$ (lanes 4 and 9 ), $95^{\circ} \mathrm{C}$ (lanes 5 and 10 ) for $10 \mathrm{~min}$, respectively, under reducing conditions (in the presence of $\beta$-mercaptoethanol, $+\beta \mathrm{ME}$ ) and nonreducing conditions (in the absence of $\beta$-mercaptoethanol, $-\beta \mathrm{ME})$. Lane $\mathrm{M}$ represents the molecular marker. Color version available online.

the surface hydrophobicity index was, the more intense the protein molecule unfolding. As shown in Figure 4, the surface hydrophobicity index increased slowly with the enhancement of temperature at 65 and $75^{\circ} \mathrm{C}$, then enhanced sharply and reached the maximum at $85^{\circ} \mathrm{C}$. When temperature was up to $95^{\circ} \mathrm{C}$, the surface hydrophobicity index decreased in some degree, but still higher than that at $75^{\circ} \mathrm{C}$.

\section{Particle Size Distribution of Yak Milk Proteins After Heat Treatment}

The particle size volume distributions of yak milk after heat treatment at different temperatures were shown in Figure 5. It suggested that heating resulted in a shift in distribution profiles toward larger particles.

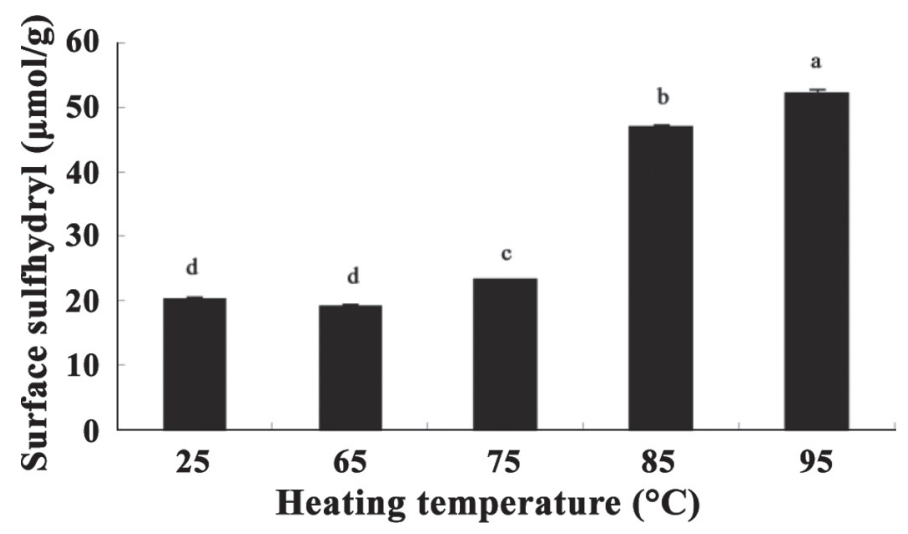

Figure 3. The surface sulfhydryl content of yak milk samples after being heated at $25,65,75,85$, and $95^{\circ} \mathrm{C}$ for $10 \mathrm{~min}$, respectively. Different letters $(\mathrm{a}-\mathrm{d})$ indicate significant differences $(P<0.05)$ among samples. Error bars represent SD of 3 independent experiments. 


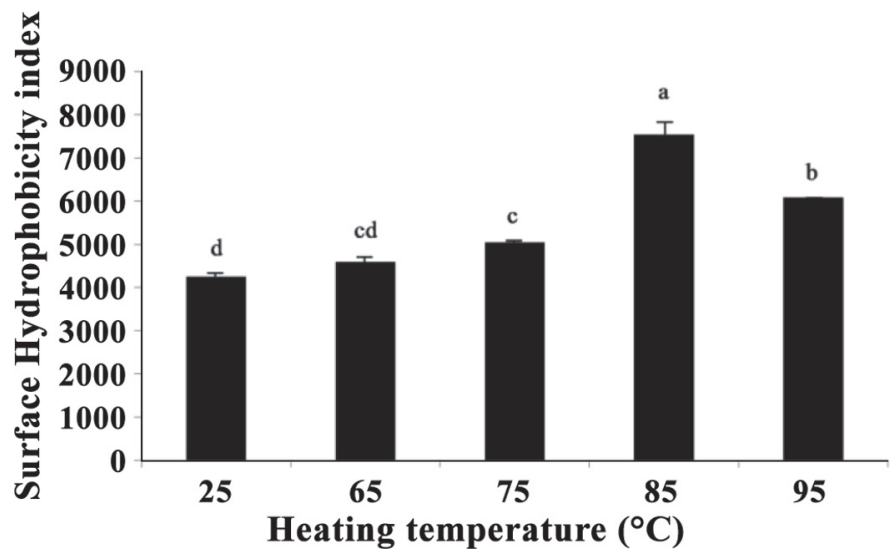

Figure 4. The surface hydrophobicity of yak milk samples after being heated at $25,65,75,85$, and $95^{\circ} \mathrm{C}$ for $10 \mathrm{~min}$, respectively. Different letters $(\mathrm{a}-\mathrm{d})$ at the top of the columns indicate significant differences $(P<0.05)$ among samples. Error bars represent SD of 3 independent experiments.

Most particles in the unheated yak milk and yak milk heated at 65 and $75^{\circ} \mathrm{C}$ distributed at the size of around $0.14 \mu \mathrm{m}$. Significant shifts occurred in volume distributions with larger size particles at 85 and $95^{\circ} \mathrm{C}$, which was in accordance with the whey protein nitrogen index results.

\section{Effect of Heat Treatment on the Microstructure of Yak Milk Protein}

Heat stability and aggregation behavior of yak milk protein heated at different temperatures were observed by laser scanning confocal microscope and

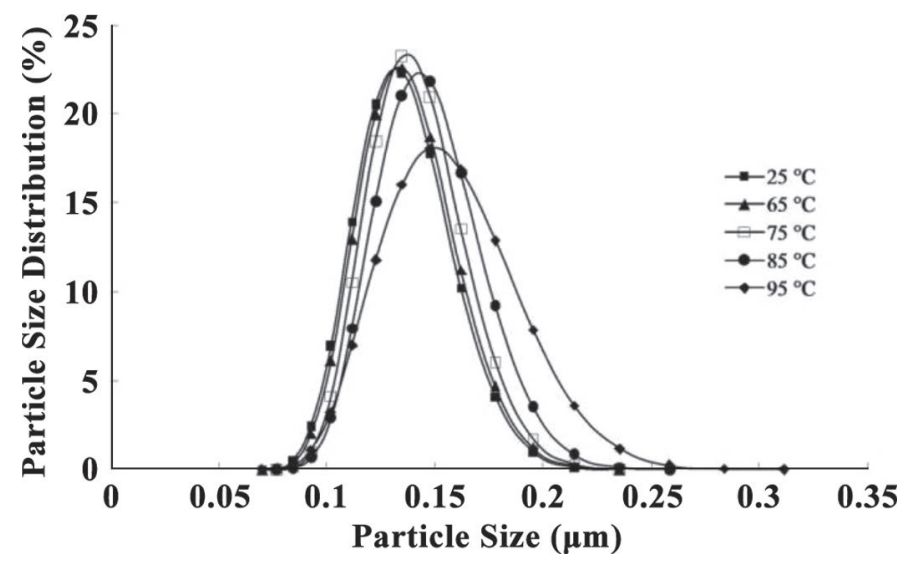

Figure 5. Effect of different thermal treatments on the particle size distribution of yak milk samples: $\mathbf{\square}$, yak milk heated at $25^{\circ} \mathrm{C}$ for $10 \mathrm{~min}$; $\boldsymbol{\Delta}$, yak milk heated at $65^{\circ} \mathrm{C}$ for $10 \mathrm{~min}$; $\square$, yak milk heated at $75^{\circ} \mathrm{C}$ for $10 \mathrm{~min}$;, yak milk heated at $85^{\circ} \mathrm{C}$ for $10 \mathrm{~min}$; , yak milk heated at $95^{\circ} \mathrm{C}$ for $10 \mathrm{~min}$.

optical microscope, as shown in Figure 6. The white light granules in Figure 6 (1) were yak milk aggregates. Compared with unheated yak milk $\left(25^{\circ} \mathrm{C}\right)$ in which aggregates distributed rarely (A), the protein aggregates distributed in a higher density with the enhancement of temperature $(\mathrm{B}, \mathrm{C}, \mathrm{D}, \mathrm{E})$, which demonstrated that more proteins began to aggregate. As shown in Figure 6 (2), the surface of the unheated yak milk sample $\left(25^{\circ} \mathrm{C}\right.$, a) was homogeneous and smooth. When the yak milk was heated at 65 and $75^{\circ} \mathrm{C}$, significant visible differences $(b, c)$ did not occur. When temperature increased further to above $85^{\circ} \mathrm{C}$, the surface of yak milk became rough with some big protein aggregates $(d)$.

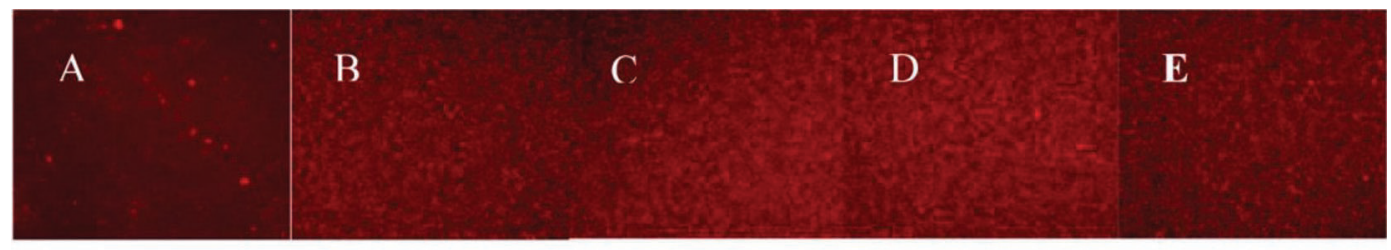

(1)

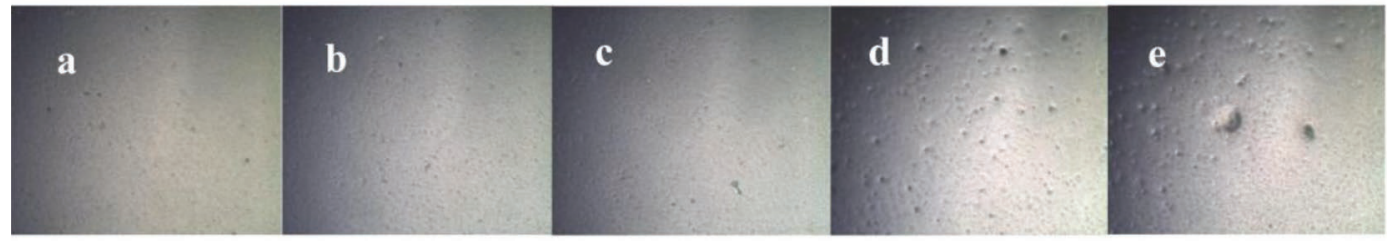

(2)

Figure 6. (1) Laser scanning confocal micrographs of yak milk samples after being heated at $25^{\circ} \mathrm{C}(\mathrm{A}), 65^{\circ} \mathrm{C}(\mathrm{B}), 75^{\circ} \mathrm{C}(\mathrm{C}), 85^{\circ} \mathrm{C}(\mathrm{D})$, and $95^{\circ} \mathrm{C}$ (E) for $10 \mathrm{~min}$, respectively. The dyed caseins appear as white light (red) granules, whereas the aqueous phase or pores are dark, irregularly shaped areas. (2) Optical microscope photographs of yak milk samples after being heated at $25^{\circ} \mathrm{C}(\mathrm{a}), 65^{\circ} \mathrm{C}(\mathrm{b}), 75^{\circ} \mathrm{C}(\mathrm{c}), 85^{\circ} \mathrm{C}(\mathrm{d})$, and $95^{\circ} \mathrm{C}(\mathrm{e})$ for $10 \mathrm{~min}$, respectively. Color version available online. 


\section{DISCUSSION}

Heat treatment affected the interaction behavior of yak milk proteins. We demonstrated that higher temperatures caused more protein-protein interactions. The OD value of yak milk proteins in this study demonstrated that when the heating temperature was up to $65^{\circ} \mathrm{C}$, whey proteins in yak milk began to denature, which was in accordance with the previous study (Yang et al., 2014). When the heating temperature continuously increased to more than $75^{\circ} \mathrm{C}$, more whey proteins denatured, with the increase of association of denatured whey proteins with casein micelles (Li et al., 2014). In this process, with the enhancement of temperature at more than $65^{\circ} \mathrm{C}, \beta-\mathrm{LG}$ formed small aggregates at first, and then became larger (Anema, 2000). When the heating temperature increased further, the $\alpha$-LA began to denature and formed complexes with denatured $\beta-\mathrm{LG}$, and interacted with $\kappa$-casein on the surface of casein micelles (Jang and Swaisgood, 1990).

Protein aggregations could also be shown in the particle size distribution and microstructure in the present study. When the heating temperature was higher than $65^{\circ} \mathrm{C}$, the average particle size in the system increased with the association of denatured whey proteins with casein micelles, and especially significantly at 85 and $95^{\circ} \mathrm{C}$. The microstructure of the system investigated by a laser scanning confocal microscope and an optical microscope showed that the stability of the yak milk system was reduced because of interactions between proteins after heat treatment. It has been reported that the enlargement of the diameter of casein micelles was due to the attachment of $\beta-\mathrm{LG} / \kappa-\mathrm{CN}$ complexes to the surface via disulfide bonds (Corredig and Dalgleish, 1996).

The SDS-PAGE patterns showed that when the heating temperature reached above $75^{\circ} \mathrm{C}$, extensive aggregation occurred in yak milk proteins, the intensity of $\kappa-\mathrm{CN}$ and whey protein bands decreased especially at $95^{\circ} \mathrm{C}$, and the $\alpha$-LA and $\beta$-LG bands almost disappeared, as shown in nonreducing SDS-PAGE (Figure $5,-\beta \mathrm{ME})$. Heat treatment of milk above $70^{\circ} \mathrm{C}$ causes denaturation of whey proteins, the whey proteins unfold, irreversibly denature, and eventually aggregate through hydrophobic bonding and thiol/disulfide exchanges with themselves and with, essentially, $\kappa-\mathrm{CN}$, leading to the so-called whey protein/ $\kappa$-CN complexes, which determine many characteristics of milk and milk products (Cho et al., 2003; Donato and Guyomarc'h, 2009). The degree of interaction between whey proteins and $\kappa$ - $\mathrm{CN}$ depends on the heating time and temperature, protein concentrations, $\mathrm{pH}$, and the presence and concentrations of milk salts. Therefore, Figure 5 shows the aggregation almost disappears except for $95^{\circ} \mathrm{C}$, and the intensities of whey protein bands and casein bands are almost the same as the unheated sample $\left(25^{\circ} \mathrm{C}\right)$ in the presence of $\beta$-mercaptoethanol, which can reduce the disulfide bonds (Figure $5,+\beta \mathrm{ME}$ ). It indicated that the aggregation behavior of yak milk proteins, especially interactions between $\kappa-\mathrm{CN}$ and $\alpha-\mathrm{LA}$ or $\beta-\mathrm{LG}$, was almost completely due to the formation of disulfide bonds at heating temperature of 75 and $85^{\circ} \mathrm{C}$, which identified with a previous study about the heat-induced aggregation of whey proteins (De la Fuente et al., 2002). But when yak milk is heated at $95^{\circ} \mathrm{C}$, other interactions might exist. These results are similar to the conclusions about cow milk that heating causes a progressive loss of the native protein structures, leading to the formation of intermolecular disulfide-linked aggregates apparently via hydrophobically linked intermediate stages (Calvo et al., 1995). So the surface sulfhydryl group content and the surface hydrophobicity index were investigated. It was known that about $90 \%$ sulfhydryl group in cow milk existed in $\beta-\mathrm{LG}$, the free thiol group was masked in the hydrophobic interior of the protein and did not normally participate in a disulfide linkage. But the reactivity can be markedly increased by protein unfolding induced by, for example, thermal treatment (Sava et al., 2005). So when the heating temperature was up to 85 and $95^{\circ} \mathrm{C}$, the $\beta$-LG denatured with the molecular chain unfolded, which exposed inner hidden thiol groups, making surface sulfhydryl content increase in yak milk. It also provided an evidence for the formation of disulfide-linked aggregates in heated yak milk. In addition, hydrophobic interaction is also the main driving force to maintain protein structure, and the protein conformation is conducive to the formation of electrostatic attraction and the effect of hydrogen bonding. During heating, the proteins denatured to a certain degree, and the polypeptide chains unfolded, which exposed inner hidden hydrophobic groups of yak milk proteins, making surface hydrophobicity increase with the temperature increasing to above $65^{\circ} \mathrm{C}$ (Croguennec et al., 2004). In this study, the surface hydrophobicity index increased with the enhancement of temperature ranging from 65 to $85^{\circ} \mathrm{C}$, but at $95^{\circ} \mathrm{C}$ the surface hydrophobicity index decreased to some degree; this might be because heat treatment above $85^{\circ} \mathrm{C}$ increased the molecular motion and formed aggregates, which caused the exposed hydrophobic groups to wrap inside again.

\section{CONCLUSIONS}

At temperatures above $65^{\circ} \mathrm{C}$, whey proteins in yak milk began to denature and form complexes with themselves or with other proteins. As temperatures exceeded $75^{\circ} \mathrm{C}$, especially at 85 and $95^{\circ} \mathrm{C}$, yak milk proteins unfolded and exposed their inner hydrophobic groups, 
and the surface sulfhydryl content also increased. Heat treatment induced denaturation of yak milk proteins, which was accompanied by a certain degree of aggregation. The main force between protein aggregates was thiol/disulfide exchange interaction when yak milk was heated below $85^{\circ} \mathrm{C}$. When the temperature was above $85^{\circ} \mathrm{C}$, hydrophobic interactions between heated yak milk proteins occurred in addition to disulfide bonds.

\section{ACKNOWLEDGMENTS}

We are grateful for the financial support for this work by Lhasa Key Science and Technology Project (20150118), the National Dairy Industry Technology System-Beijing Innovation Team (NDITS-BIT), National Natural Science Foundation of China (31371753), and Key Projects in the National Science \& Technology Pillar Program during the Twelfth Five-Year Plan Period (2013BAD18B12-05). All authors have read and approved the final manuscript.

\section{REFERENCES}

Alizadeh-Pasdar, N., and E. C. Li-Chan. 2000. Comparison of protein surface hydrophobicity measured at various $\mathrm{pH}$ values using three different fluorescent probes. J. Agric. Food Chem. 48:328-334.

Anema, S. G. 2000. Effect of milk concentration on the irreversible thermal denaturation and disulfide aggregation of $\beta$-lactoglobulin. J. Agric. Food Chem. 48:4168-4175.

Beveridge, T., S. J. Toma, and S. Nakai. 1974. Determination of SHand SS- groups in some food proteins using Ellman's reagent. J. Food Sci. 39:49-51.

Boye, J. I., and I. Alli. 2000. Thermal denaturation of mixtures of $\alpha$-lactalbumin and $\beta$-lactoglobulin: a differential scanning calorimetric study. Food Res. Int. 33:673-682.

Calvo, M. M., A. Law, and J. Leaver. 1995. Heat-induced interactions between serum albumin, immunoglobulin, and $\kappa$-casein inhibit the primary phase of renneting. J. Agric. Food Chem. 43:2823-2827.

Cho, Y., H. Singh, and L. K. Creamer. 2003. Heat-induced interactions of $\beta$-lactoglobulin A and $\kappa$-casein B in a model system. J. Dairy Res. 70:61-71.

Corredig, M., and D. G. Dalgleish. 1996. Effect of temperature and pH on the interactions of whey proteins with casein micelles in skim milk. Food Res. Int. 29:49-55.

Croguennec, T., B. T. O'Kennedy, and R. Mehra. 2004. Heat-induced denaturation/aggregation of $\beta$-lactoglobulin A and B: kinetics of the first intermediates formed. Int. Dairy J. 14:399-409.

De la Fuente, M. A., H. Singh, and Y. Hemar. 2002. Recent advances in the characterisation of heat-induced aggregates and intermediates of whey proteins. Trends Food Sci. Technol. 13:262-274.
Donato, L., and F. Guyomarc'h. 2009. Formation and properties of the whey protein/ $\kappa$-casein complexes in heated skim milk-A review. Dairy Sci. Technol. 89:3-29.

Faka, M., M. J. Lewis, A. S. Grandison, and H. Deeth. 2009. The effect of free $\mathrm{Ca}^{2+}$ on the heat stability and other characteristics of low-heat skim milk powder. Int. Dairy J. 19:386-392.

Guyomarc'h, F., C. Queguiner, A. J. R. Law, D. S. Horne, and D. G. Dalgleish. 2003. Role of the soluble and micelle-bound heatinduced protein aggregates on network formation in acid skim milk gels. J. Agric. Food Chem. 51:7743-7750.

Jang, H. D., and H. E. Swaisgood. 1990. Disulfide bond formation between thermally denatured $\beta$-lactoglobulin and $\kappa$-casein in casein micelles. J. Dairy Sci. 73:900-904.

Laemmli, U. K. 1970. Cleavage of structural proteins during the assembly of the head of the bacteriophage T4. Nature 227:680-685.

Li, H., Y. Ma, A. Dong, J. Wang, Q. Li, S. He, and J. L. Maubois. 2010. Protein composition of yak milk. Dairy Sci. Technol. 90:111-117.

Li, H., Y. Ma, Q. Li, J. Wang, J. Cheng, J. Xue, and J. Shi. 2011. The chemical composition and nitrogen distribution of Chinese yak (Maiwa) milk. Int. J. Mol. Sci. 12:4885-4895.

Li, Q., Y. Ma, S. He, W. Elfalleh, W. Xu, and J. Wang. 2014. Effect of $\mathrm{pH}$ on heat stability of yak milk protein. Int. Dairy J. 35:102-105.

O'Kennedy, B. T., and J. S. Mounsey. 2006. Control of heat-induced aggregation of whey proteins using casein. J. Agric. Food Chem. 54:5637-5642.

Oldfield, D. J., H. Singh, M. W. Taylor, and K. N. Pearce. 2000. Heatinduced interactions of $\beta$-lactoglobulin and $\alpha$-lactalbumin with the casein micelle in pH-adjusted skim milk. Int. Dairy J. 10:509-518.

Rattray, W., and P. Jelen. 1997. Thermal stability of skim milk/whey protein solution blends. Food Res. Int. 30:327-334.

Sava, N., I. Van der Plancken, W. Claeys, and M. Hendrickx. 2005. The kinetics of heat-induced structural changes of beta-lactoglobulin. J. Dairy Sci. 88:1646-1653.

Singh, M. J., J. Chandrapala, P. Udabage, I. McKinnon, and M. A. Augustin. 2015. Heat-induced changes in the properties of modified skim milks with different casein to whey protein ratios. J. Dairy Res. 82:135-142.

Smith, P. K., R. I. Krohn, G. T. Hermanson, A. K. Mallia, F. H. Gartner, M. D. Provenzano, E. K. Fujimoto, N. M. Goeke, B. J. Olson, and D. C. Klenk. 1985. Measurement of protein using bicinchoninic acid. Anal. Biochem. 150:76-85.

Taterka, H., and M. Castillo. 2015. The effect of whey protein denaturation on light backscatter and particle size of the casein micelle as a function of $\mathrm{pH}$ and heat-treatment temperature. Int. Dairy J. $48: 53-59$.

Vyas, H. K., and P. S. Tong. 2004. Impact of source and level of calcium fortification on the heat stability of reconstituted skim milk powder. J. Dairy Sci. 87:1177-1180.

Wang, P., H. Liu, P. Wen, H. Zhang, H. Guo, and F. Ren. 2013. The composition, size and hydration of yak casein micelles. Int. Dairy J. 31:107-110.

Xu, W. Y., S. H. He, Y. Ma, Y. X. Zhang, Q. M. Li, L. F. Wang, and R. Wang. 2015. Effect of $\mathrm{pH}$ on the formation of serum heatinduced protein aggregates in heated yak milk. Int. J Dairy Technol. 68:342-348.

Yang, M., W. Zhang, P. Wen, Y. Zhang, and Q. Liang. 2014. Heat stability of yak micellar casein as affected by heat treatment temperature and duration. Dairy Sci. Technol. 94:469-481. 